DOI: http://dx.doi.org/10.33846/hn40504

http://heanoti.com/index.php/hn

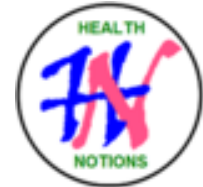

RESEARCH ARTICLE

URL of this article: http://heanoti.com/index.php/hn/article/view/hn40504

\title{
Contraception Reduces Breast Milk Protein Level of Breastfeeding Mothers in Jember,
} East Java, Indonesia

\author{
Nuzula Irfa Nuriana ${ }^{1(\mathrm{CA})}$, FX. Ady Soesetijo ${ }^{2}$, Candra Bumi ${ }^{3}$ \\ ${ }^{1(\mathrm{CA})}$ Postgraduate Program of Public Health Science, Universitas Jember, Indonesia; nuzula1995@ gmail.com \\ (Corresponding Author) \\ ${ }^{2}$ Faculty of Dentistry, Universitas Jember, Indonesia; fxadysdrg@gmail.com \\ ${ }^{3}$ Faculty of Public Health, Universitas Jember, Indonesia; candrabumi@unej.ac.id
}

\begin{abstract}
The protein level of breast milk affected the growth and development of infants. Protein has special function which is irreplaceable by other nutrients to form and protect the body cells. Protein also plays a role as antibody, functions as the body defense mechanism against various diseases and infections. Infant death in Indonesia is mostly caused by respiratory tract infections and diarrhea. Breastfeeding can help to prevent the occurrence of morbidity and mortality of infants and toddlers in which the breast milk contains many essential nutrients needed by the body, one of them is protein. The aim of this research was to analyze the effect of contraception on breast milk protein level of breastfeeding mothers in Jember regency. The design of this research was observational analytic with cross sectional approach, using statistic test of logistic regression. The result of the research showed that the effect of contraception on the protein level of breast milk obtained p-value $=0.021$ with $\operatorname{Exp}(B)=566.263$. Based on the research, it can be concluded that there was an effect of contraception on breast milk protein level.
\end{abstract}

Keywords: infection; breastmilk protein; contraception

\section{Background}

The protein content of breast milk influences the baby's growth and development. Protein is the source of amino acid that contain element of $\mathrm{C}, \mathrm{H}, \mathrm{O}$, and $\mathrm{N}$ which cannot be found in fat or carbohydrate. Protein has a special function that cannot be substituted by other nutritional substances in it covers building and maintaining the body's cells and tissues. In each life cell, protein is an essential part. Most of the body's tissue, protein is the dominant component after water. Protein is catalyzed in the body as the source of energy if the supply of carbohydrate and fat is not sufficient. Protein is stored in muscles, bones, blood, skin, cartilage, and lymph. It also forms antibody which functions in the body defense mechanism against various diseases and infections ${ }^{(1)}$.

Infant Mortality Rate (IMR) is the indicator of health status which determines the society health degree. One of the health problems in Indonesia was the high $\mathrm{IMR}^{(2)}$. The infant death in Indonesia was mostly caused by respiratory tract infections and diarrhea. The proportion of infant death due to respiratory tract infection was $27.6 \%$ and diarrhea of $9.4 \%$. Breastfeeding was one of the attempts to prevent diarrhea. Breast milk is the best and natural diet for infant because those infants who did not get breast milk had a 17 times greater risk of suffering diarrhea and 4 times more likely to suffer upper respiratory tract infection ${ }^{(3)}$. The result of Indonesia Demographic and Health Survey in 2017 showed Neonatal Mortality Rate (NMR) of 15 per 1,000 live births, Infant Mortality Rate of 24 per 1000 live births, and Toddler Mortality Rate of 32 per 1,000 live births. The morbidity of pneumonia of infant was $2.2 \%$, toddler of $3 \%$, while the mortality of infant was $23.8 \%$ and toddler of $15.5 \%^{(4)}$. The incidence of pneumonia on toddler in East Java in 2018 was as many as $1.90 \%$ and in 2013 was $1.65 \%{ }^{(5)}$. 
As reported by the Provincial Health Office of East Java (2018), it revealed that the Infant Mortality Rate in Jember Regency in 2017 as many as 207 cases and in 2018 as many as 166 cases. The causes of Infant Mortality in Jember Regency were LBW (Low Birth Weight), asphyxia, infection and pneumonia. The data obtained from the Health Office of Jember Regency (2018) showed that Patrang Health Center was one of the health centers that had high number of infant mortality cases, in which there were as many as 18 cases and the number of cases of pneumonia under five was high, as many as $109 \operatorname{cases}^{(6)}$.

\section{Purpose}

The purpose of this research was to analyze the effect of the contraception method on breast milk protein content at Patrang Community Health Center, Jember.

\section{METHODS}

The research design used was analytic observational design with cross sectional approach. This research was conducted at Patrang Community Health Center and the Food Biochemical Analysis Laboratory of State Polytechnic of Jember in December 2019 - January 2020. The samples of breastfeeding mothers who met the inclusion and exclusion criteria were 43 respondents. The data collection instruments used in this research were a questionnaire to determine the contraception method used by breastfeeding mothers and Kjeldahl method to analyze breast milk protein content. The statistical test used to analyze the effect of the contraception method on breast milk protein content was a logistic regression test.

\section{RESULTS}

\section{The Characteristics of Breastfeeding Mothers at Patrang Community Health Center, Jember}

We classified 43 respondents in the working area of Patrang Community Health Center in Jember based on age and parity. The instrument used to collect the data was questionnaire. Based on the data obtained, we can present the characteristics of the respondents on Table 1.

Table 1. The individual characteristics of breastfeeding mothers

\begin{tabular}{clcc}
\hline \multirow{2}{*}{ Individual Characteristic } & \multicolumn{2}{c}{ Total } \\
\cline { 3 - 4 } & & Frequency & Percentage \\
\hline \multirow{3}{*}{ Age } & $<20 \&>35$ years old & 15 & 34.9 \\
& $20-35$ years old & 28 & 65.1 \\
\cline { 2 - 4 } & Total & 43 & 100 \\
\hline \multirow{3}{*}{ Parity } & 1 child & 14 & 32.6 \\
& $>1$ child & 29 & 67.4 \\
\cline { 2 - 4 } & Total & 43 & 100 \\
\hline
\end{tabular}

Table 1 shows that 28 respondents $(65.1 \%)$ were in the category of ideal age (20 -35 yo) and 29 respondents (67.4) had children $>1$.

\section{The Contraception Method of Breastfeeding Mothers at Patrang Community Health Center, Jember}

Table 2. The distribution of contraception method

\begin{tabular}{ccc}
\hline Contraception method & Frequency & Percentage \\
\hline Progesterone hormonal & 18 & 41.9 \\
Combined hormonal & 16 & 37.2 \\
Non-hormonal & 9 & 20.9 \\
\hline Total & 43 & 100 \\
\hline
\end{tabular}


Table 2 shows that the majority of respondents used progesterone hormonal contraception method were $18(41.9 \%)$.

The Protein Levels of Breast Milk on Breastfeeding Mothers at Patrang Community Health Center, Jember

Table 3. The distribution of breast milk protein levels

\begin{tabular}{ccc}
\hline $\begin{array}{c}\text { The protein levels of } \\
\text { breast milk }\end{array}$ & Frequency & Percentage \\
\hline $\begin{array}{c}\text { Adequate } \\
\text { Less }\end{array}$ & 26 & 60.5 \\
\hline Total & 17 & 39.5 \\
\hline
\end{tabular}

Table 3 shows that the majority of respondents who had sufficient content of breast milk protein were 26 $(60.5 \%)$

The Correlation Between Contraception Method and the Protein Levels of Breast Milk on Breastfeeding Mother at Patrang Community Health Center, Jember

Table 4. The result of logistic regression test

\begin{tabular}{|c|c|c|c|c|c|c|}
\hline \multirow{3}{*}{ Contraception method } & \multicolumn{4}{|c|}{ The protein level of breast milk } & \multirow{3}{*}{ P-value } & \multirow{3}{*}{$\operatorname{Exp}(b)$} \\
\hline & \multicolumn{2}{|c|}{ Less } & \multicolumn{2}{|c|}{ Adequate } & & \\
\hline & Frequency & Percentage & Frequency & Percentage & & \\
\hline Combined hormonal & 11 & 25.6 & 5 & 11.6 & & \\
\hline Progesterone hormonal & 4 & 9.3 & 14 & 32.6 & 0.021 & 566.263 \\
\hline Non-hormonal & 2 & 4.7 & 7 & 16.3 & & \\
\hline
\end{tabular}

The result of data analysis on Table 4 showed that there was a correlation between contraception and the protein level of breast milk due to $\mathrm{p}$-value $=0.021$

\section{DISCUSSION}

The process of breast degeneration is related to the size and alveoli gland which gets apoptosis when they reach above 30 years and it decreases the production of breast milk ${ }^{(7)}$. Most respondents were at the ideal age of 20-35 years. Rahmawati \& Prayogi (2017) on their research pointed out that there was a relationship between maternal age and the breast milk production ${ }^{(8)}$.

Most respondents gave birth to more than 1 child (multipara). Parity is related to mother's experience while giving birth, a safe childbirth for mother who is going to have the second and third children and so on in which it reduces their maternal health. Experience is an important thing to foster their awareness of lactation management. Mother's experience depends on the number of children born. Mother who gives birth to more than one child is likely to breast feeding their babies ${ }^{(9)}$. A research done by Burianova, etc (2019) stated that the content of macronutrient concentration from breast milk is related to obesity, parity and smoking habit ${ }^{(10) \text {. }}$

The research also found that the majority of respondents used progesterone-hormonal contraception. As many as 18 respondents used progesterone-hormonal contraception, 16 respondents used combined-hormonal contraception and 9 respondents used non-hormonal contraception. Progestin contraception has no effect on the production and expenditure of milk, the function of progestin hormone has an effect on the growth and size of the alveoli ${ }^{(11)}$. This hormone does not affect the lactation and in opposite, improves the quantity of breast milk production (increasing the production of breast milk) and in addition, it does not affect the composition of breast milk $^{(12)}$. The contraception containing estrogen holds down FSH so that it is able to give stimulation to the anterior pituitary lobe to release luteinizing hormone. The production of luteinizing hormone is influenced by the releasing hormone distributed and from hypothalamus to pituitary, the secretion of luteinizing hormone 
makes hypothalamus release prolactin inhibiting factor ${ }^{(13)}$. Moreover, non-hormonal contraception also has no effect on breast milk and is effective in preventing the pregnancy ${ }^{(14)}$.

According to the results of this research, most respondents had the sufficient level on the protein of breast milk. The protein of breast milk binds vitamin B12 to have a control on the intestinal flora competitively. The protein binding by vitamin B12 reduces vitamin B12 needed by the pathogenic bacteria for its growth. High lactose, phosphate level, low buffering capacity and bifidus factors impact the intestinal flora whose contributions are on the growth of lactobacilus bifidus. These microbes transform lactose to lactic acid and acetic acid, the acidic situation in intestinal fluid obstructed the growth of E. Coli bacteria and other pathogenic bacteria $^{(15)}$. Breast milk is composed of complex fluids with large amounts of protein, cells and other components, immunological influences associated with breast milk that is rich in antibodies. However, sIgA is the most numerous one, which protect the mucous membranes of the digestive and respiratory tracts. IgA secretory is the main source of immunity, $\mathrm{IgA}$ contained in maternal antibodies obtained from the digestive and respiratory immune systems that were carried through blood and lymphatic circulation to the breast glands and excreted through breast milk $^{(16)}$.

Based on the analysis results on the effect of contraception method on breast milk protein level of breastfeeding mothers in Patrang Health Center Working Area showed a p-value of 0.021, which means that there was an effect of contraception on breast milk protein level. A total of 16 respondents used combined contraception, 11 respondents with less milk protein level and 5 respondents with adequate protein level. A total of 18 respondents used progesterone contraception, 4 respondents with less breast milk protein level and 14 respondents with adequate protein level. Moreover, 9 respondents used non-hormonal contraception, 2 respondents with less breast milk protein level and 7 respondents with adequate breast milk protein level.

Combined contraception contains estrogen in which high estrogen level in contraception suppressed FSH thereby stimulating the anterior pituitary lobe to secrete luteinizing hormone. The production of luteinizing hormone under the influence of releasing hormone that was transmitted from the hypothalamus to the pituitary, the secretion of luteinizing hormones caused the hypothalamus to release prolactin inhibiting factor (PIF) which was considered as dopamine. Dopamine reduced prolactin secretion up to ten times and reduced the content of breast milk itself. If prolactin secretion was inhibited, the alveoli cells in the breast did not produce milk. So that in the absence of milk production, milk expenditure was also hampered. Contraception that did not affect the production and expenditure of milk were non-hormonal method and hormonal method that only contained progesterone. Another research by Kapp and Curtis (2010) showed that the effect of combined contraception pills among breastfeeding women had an impact on the inconsistency of milk concentration and production ${ }^{(17)}$.

\section{CONCLUSION}

In this research, it can be concluded that the majority of mothers were in the ideal age category (20-35 yrs) and they gave birth to children more than once (multipara). The analysis results on the effect of contraception method on breast milk protein level of breastfeeding mothers showed that contraception affected the breast milk protein level. Contraception with Estrogen suppressed FSH thereby stimulating the anterior pituitary lobe to release hormone luteinizing. The production of luteinizing hormone under the influence of releasing hormone that was transmitted from the hypothalamus to the pituitary, the secretion of luteinizing hormone caused the hypothalamus to release prolactin inhibiting factors so as to reduce the production and levels of breast milk protein of breastfeeding mothers.

\section{REFERENCES}

1. Harti A. Health Biochemistry. Yogyakarta: Nuha Medika; 2014.

2. MoH-RI. Ministry of Health Strategic Plan for 2015-2019 [Internet]. 2015 [cited 2019 Sep 25]. Available from: https://www.kemkes.go.id/resources/download/info-publik/Renstra-2015.pdf

3. WHO. WHA Global Nutrition Targets 2025: Low Birth Weight Policy Brief. Geneva: WHO; 2014.

4. MoH-RI. Data and Information [Internet]. 2018 [cited 2019 Sep 28]. Available from: https://pusdatin.kemkes.go.id/resources/download/pusdatin/profil-kesehatan-indonesia/Data-danInformasi_Profil-Kesehatan-Indonesia-2017.pdf

5. MoH-RI. Basic Health Research 2018 (Riset Kesehatan Dasar 20180. Jakarta: MoH-RI; 2018.

6. Health Office of Jember Regency. Health Profile of Jember Regency. Jember: Health Office of Jember Regency; 2018.

7. Tory A. Factors Related to Exclusive Breastfeeding in the Working Area of Citeureup Community Health Center, Bogor Regency. Jakarta: UI; 2011.

8. Rahmawati, Prayogi. Analysis of Factors Influencing the Production of Mother Breast Milk (ASI) on Working Mothers. 2017. 
9. Syafneli EY. Analysis of Factors Related to Exclusive Breastfeeding in Pasir Jaya Village. Maternity and Neonatal. 2(1).

10. Burianova I, Bronsky, Pavlikova. Maternal body mass index, parity and smoking are associated with human milk macronutrient content after preterm delivery. 2018;51:36-41.

11. Prawirohardjo. National Reference Book for Maternal and Neonatal Health Services. Jakarta: PT Bina Pustaka Sarwono Prawirohardjo; 2010.

12. Hanafi. Family Planning and Contraception. Jakarta: Pustaka Sinar Harapan; 2010.

13. Purwaningsih W. The Influence of Injecting Contraception on the Expenditures of Exclusive Breastfeeding in BPS Triparyati Kemalang, Klaten Regency. Journal of Midwifery Involution. 2011;1(1): 9-19.

14. Prawirohardjo. Obstetrics. Jakarta: PT Bina Pustaka Sarwono Prawirohardjo; 2011.

15. Nirwana A. Mother Breast Milk and Formula Milk. Yogyakarta: Nuha Medika; 2014.

16. Wagner CL. Human milk and lactation. [Internet]. 2018 [cited 2020 May 1]. Available from: http://www.emedicine.com

17. Kapp N, Curtis M. Combined oral contraceptive use among breastfeeding women: a systematic review. Contraception. 2010;82:10-16. 